\title{
Developmental peculiarities of nobles' estates on the territories of distant uyezds in St. Petersburg province
}

\author{
Evgenia Shuvaeva ${ }^{1, *}$ \\ ${ }^{1}$ St. Petersburg State University of Architecture and Civil Engineering, St. Petersburg, Russia
}

\begin{abstract}
The research is devoted to studying the prerequisites for occurrence, development peculiarities and the distinctive characteristics of nobles' estates located in the territories of distant uyezds of the St. Petersburg province. Such presentable estates have a number of characteristics that are distinctive from ordinary noble estates. The following are considered as examples: Rapti estate in Luzhskii, Kotly estate in Yamburgskii, Volyshovo estate in Gdovskii, Pokrovskoe estate in Novoladozhskii districts. The studies of previous years affecting the manor housing of the Leningrad Region are analyzed in order to determine the knowledge level on the topic.
\end{abstract}

\section{Introduction}

The brisk construction of suburban nobles' estates in the St. Petersburg province began during the reign of Elizaveta Petrovna, in the third quarter of the 18th century. Then, the further formation of manor complexes continued under Catherine II on plots of land newly acquired by the nobles. At the same time there was a process of changing and rebuilding the already existing groups of houses.

In the territory adjacent to the capital, along with the imperial suburban palace and garden complexes and nobles' estates, there was a special type of projects, designated as "nearby estates of the highest nobility".

Studying suburban estates located in distant uyezds of St. Petersburg province (Luzhskii, Gdovskii, Yamburgskii, Novoladozhskii) made it possible to identify a number of objects that were also owned by nobles of high social status. They were close to the court and had a rank not lower than fourth in the ranking chart. At the moment, information has been collected about 105 distant estates of the highest nobility.

Information on the estates is contained in publications devoted to the history of St. Petersburg, works on the theory and history of architecture, landscape gardening art by the following authors: M. I. Pylyaev, N. N. Wrangel, S. V. Sementsov, N. V. Murashova I.A. Bondarenko, T. B. Dubyago, T.P. Kazhdan, A. Yu. Nizovsky, M.A. Ilyin and others. In one of the first studies on the manor parks of the Leningrad Region, 516 objects were examined

\footnotetext{
* Corresponding author: e.u.shuvaeva@mail.ru
} 
by I.V. Barsova, including 104 estates identified and examined on-site. The typological aspect of the landscape gardening complex of rural noble estates is described in the thesis by S. E. Guseva. According to the study carried out by T. E. Isachenko, 476 noble estates were identified, 154 estate complexes were inspected. The studies of O. V. Litvintseva are devoted to the estates of the Novgorod province, part of the uyezds of which bordered on the distant uyezds of the St. Petersburg province. However, the phenomenon of nobles' estates as a special resettlement system for the upper society layers in the adjacent territories, which influenced the development of the historical agglomeration, has not been previously studied.

\section{Materials and methods}

As a subject, the nobles' estates located in the distant uyezds of the St. Petersburg province are considered. The research goal is to identify the characteristic features of these estates and their portrayal on specific examples of estates of Gdovskii, Luzhskii, Yamburgskii and Novoladozhskii uyezds. The studies are based on analyzing the numerous archival and literary sources, the materials of the author's field surveys are also considered.

\section{Results and discussion}

Among the two thousand of nobles' estates that existed in the territory of the St. Petersburg province by the beginning of the 20th century, an exceptional position was occupied by the estates of the highest state dignitaries, the estates of the highest nobility. They had their own unique functional, planning and compositional peculiarities distinguishing them from many suburban and rural estates.

Taking into account the remoteness radius from the capital city, manor buildings can be conditionally divided into two zones, each of which has its own characteristic peculiarities despite similar typological features. Thus, 4 uyezds located closer to the borders of the province were considered, forming the farthest zone (Gdovskii, Luzhskii and Yamburgskii on the western border and Novoladozhskii on the eastern one). By 1917, 105 nobles' estates were preserved in them, including 20 estates in the Gdovskii district, mainly located along the tributaries of the Velikaya river. 26 estates along historical roads were preserved in Luzhskii, near the Luga and Oredezh rivers. 26 estates along the ancient Narva tract are located in Yamburgskii. In Novoladozhskii uyezd, 13 estates are located along the oldest highway along the southern shore of Lake Ladoga, known since the 13th century.

Geographical peculiarities.

The settlement structure was uneven, also due to geographical features. Thus, the largest number of distant estate complexes is located on the territory of modern Volkhovskii and Luzhskii regions. This fact is due to the primary role of agriculturally convenient lands and the availability of communication lines in the formation and development of manor buildings.

For example, plots of land are densely built up along the shores of Vrevo and Cheremenetskoye lakes in the Luzhskii uyezd (Navolok, Yugostitsy, Repy, Golubkovo, Skreblovo, Borovoe, Nezhgostitsy, Busany), along the Volkhov river (Pokrovoskoe, Lyubsha, Dunino, Uspenskoe).

The area of the land.

The lands belonging to the nobility of the capital were quite extensive and were located mainly closer to St. Petersburg, and with distance they were smaller. The average area of the estate complex reached 23 hectares in Luzhskii (Merevo, Perechitsy, Zapolye), 7 hectares in Novoladozhskii (Demorovka, Sari, Uspenskoye), 18 hectares in Yamburgskii 
(Valgovitsy, Lopets, Mariengof) and 9 hectares in Gdovskii counties (Moklochno, Zayanye, Kharlamova Gora).

Over time, the areas of land holdings decreased in both near and distant estates due to the fact that they were inherited or sold in separate plots.

Functional use of the territory.

The functional use of the territory of distant estates is due to long seasonal residence, which entails the construction of an extensive economic part. Such part includes landscape elements (orchards, vegetable gardens, agricultural land) and buildings (barns, stables, cowsheds, warehouses and others). In addition, the main volume of the manor house included a sufficient number of residential premises, residential buildings were erected for service personnel on the territory (gardener's house, manager's house, and others). To date, the farm buildings made mostly from stone or brick are the best preserved ones.

\section{Accommodation peculiarities of estates.}

Estates in distant uyezds were accommodated along the main navigable rivers and historical major highways, not in a dense ring, but forming the "bushes".

The peculiarity of "bush" accommodation of estates is due to historical circumstances. Often this was due to the allocation of land to the heirs, which was accompanied by the construction of a new estate in close proximity to the main one. On average, estates in the "bushes" are separated from each other at a distance of 3-5 km and are connected by roads. Allocated estates were usually smaller.

The estates were grouped into "bushes" consisting of separate plots with manor houses and parks around them. These newly formed park manor complexes were located in road junctions, on the banks of ponds, on hillsides, ravines, in places convenient for farming, with favorable natural conditions, near villages and towns.

One estate was selected in each uyezd for a specific illustration of the identified peculiarities. Thus, one of the most representative estates in Luzhskii uyezd having the largest area of distant uyezds at the end of the XIX century is described, which had a vast territory and a large number of buildings.

Luzhskii uyezd - Rapti estate.

The estate has been known since 1616, when the Rapti village was granted to Grigory Afanasevich Bazanin by Tsar Mikhail Fedorovich Romanov "as a token of service and patience".

Stage 1 (1616 - 1849). Bazanin family ownership. According to the delimitation plan of 1781, the estate was located on a hill and occupied the territory on both sides of the Cheremenetsky and Toloni lakes (Figure 3). The description of the estate in 1783 states that the estate contained a manor house with a well and an orchard. At the beginning of the XIX century, under the court councillor Pyotr Grigoryevich Bazanin, the territory of the estate was enlarged due to the annexation of the Rakovichi and Gorka villages, new stone manor and farm houses were built.

Stage 2 (1849-1879). Ownership of an actual state councilor Alexander Andreevich Polovtsev. During this period, the estate was rebuilt due to the seasonal residence of the Polovtsev family here. New structures were added to the existing ones, such as a guest house, manager's house, gardener's house, office, horse carriage and a stable, a small park was also developed and the gardens were renovated.

Stage 3 (1879 - 1909). Ownership of Alexander Alexandrovich Polovtsev, State Secretary of Alexander III. In 1886, the transformation of the estate began, which lasted 7 years under the direction of the architect I.A. Stefanitsa. The old part of the estate and the garden had an established planning structure. The park in the new part was arranged in the French regular parks style, had an integral composition, was viewed along the axes converging in the center, the center of the composition was the palace. The economic zone was located on the eastern side of the new park. After its completion in 1892, the 
pheasantry was built in place of the barracks for workers that existed during the construction. Greenhouses were built at the same time as the palace. Archival documents dated 1905 indicate that the estate had developed cattle breeding, poultry farming, field husbandry, gardening and an apiary.

Stage 4 (1909 - 1917). Ownership of Alexander Polovtsev (stallmaster of the court of his imperial majesty). The manager was occupied with affairs on the estate during this period, since the owner's family rarely came.

Stage 5 (1917 - 1941). NKVD sanatorium was located on the estate territory, the palace building and outbuildings were operated for its needs.

During the Great Patriotic War, the Rapti village was occupied by German troops, the building of the manor house was blown up during their retreat. Only the ruins of the supporting arch and parts of the open staircase have survived. The outbuildings that have survived to date are used as administrative and residential premises.

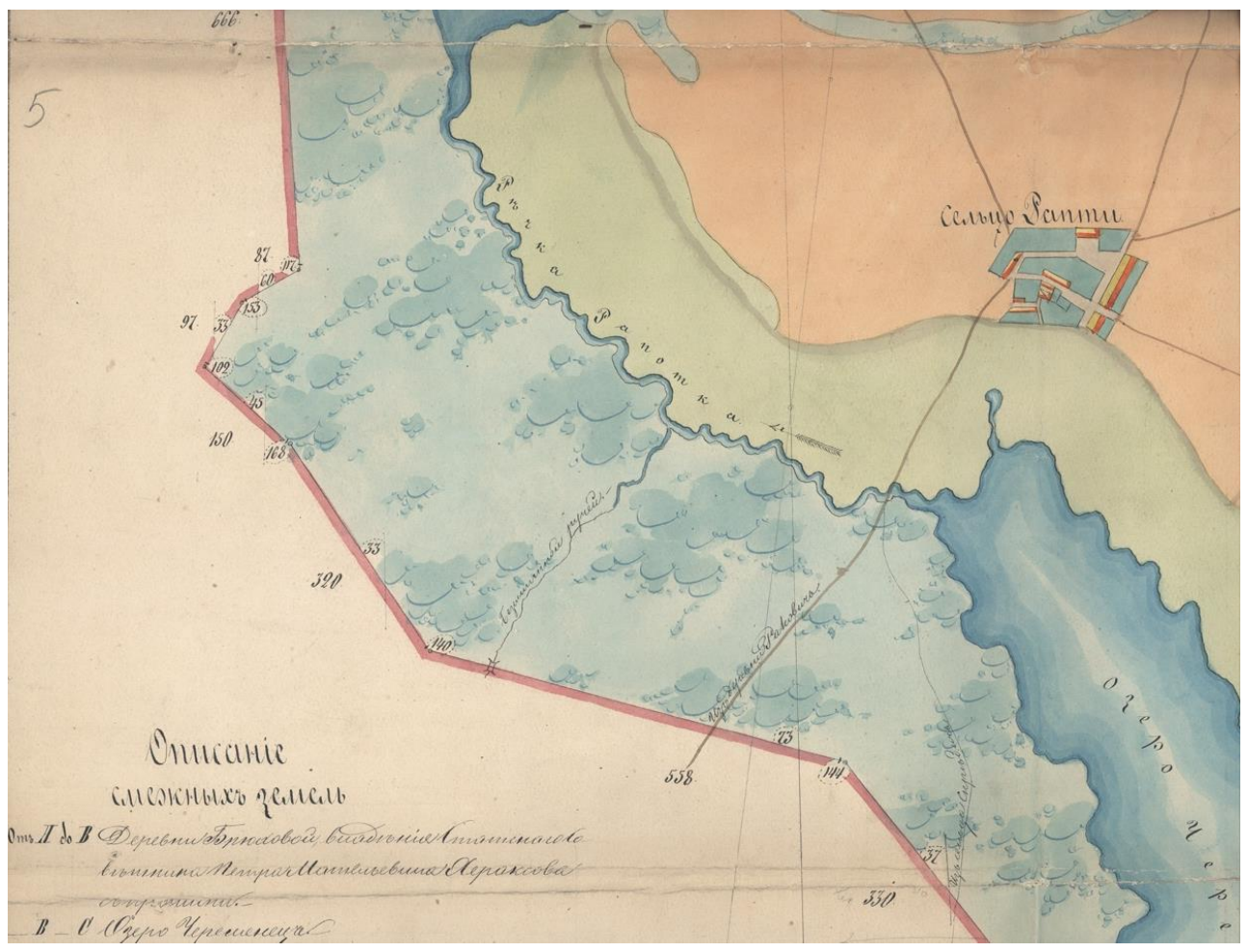

Fig. 1. Plan of the Rapti estate. 1781 CSHA SPb, F. 262, Op. 101, D. 433.

Yamburgskii uyezd is no less presentable, despite the smaller area, it has a similar number of estates of the highest nobility located on its territory.

Yamburgskii uyezd - Kotly estate.

Kotly estate is the most extensive estate of the Yamburgskii uyezd, located at the edge of the ridge terrace (Figure 4). Until 1730 the estate was public, and then transferred to Ludwig Albrecht.

Stage 1 (1730 - 1750). Major General Albrecht ownership. During this period, the first estate was built and the foundation for a regular layout was made.

Stage 2 (1750 - 1839). Ownership of Lev Ludwigovich Albrecht, then of his son Ivan Lvovich Albrecht. In the 1820s the estate was rebuilt, a stone palace was built on the site of the wooden manor house, household buildings are located along the access road. There was a Lutheran church in the south, along the axis of the main house, the Church of St. Nicholas 
the Wonderworker not far from it. It was wooden, consecrated in 1730, in 1889 it was replaced by a stone one. The regular planning structure of the estate territory is represented on the plan of 1855 , on the map of 1862 the regularity is softened.

Stage 3 (1839-1860). Ownership of Karl Ivanovich Albrecht. The estate was leased for 8 years to Friedrich Zirch, who transformed the household part, built a new drying house and rebuilt the farmyard.

Stage 4 (1860 - 1885). Ownership of Peter Karlovich Albrecht. The estate's territory increased, a sawmill was founded, barracks for workers, post office, shop, pharmacy and other household buildings were also built.

Then the estate was sequentially owned by the merchant Arkady Ivanovich Mamontov (since 1885), the wife of the merchant Nina Aleksandrovna Sapozhnikova (since 1894), Maria Alexandrovna Benois and Olga Aleksandrovna Meissner (since 1896), but no transformations were made during that period.

Currently, the planning structure has been changed, the manor house-palace, outbuildings, services, family crypt and a grotto are among the buildings survived.

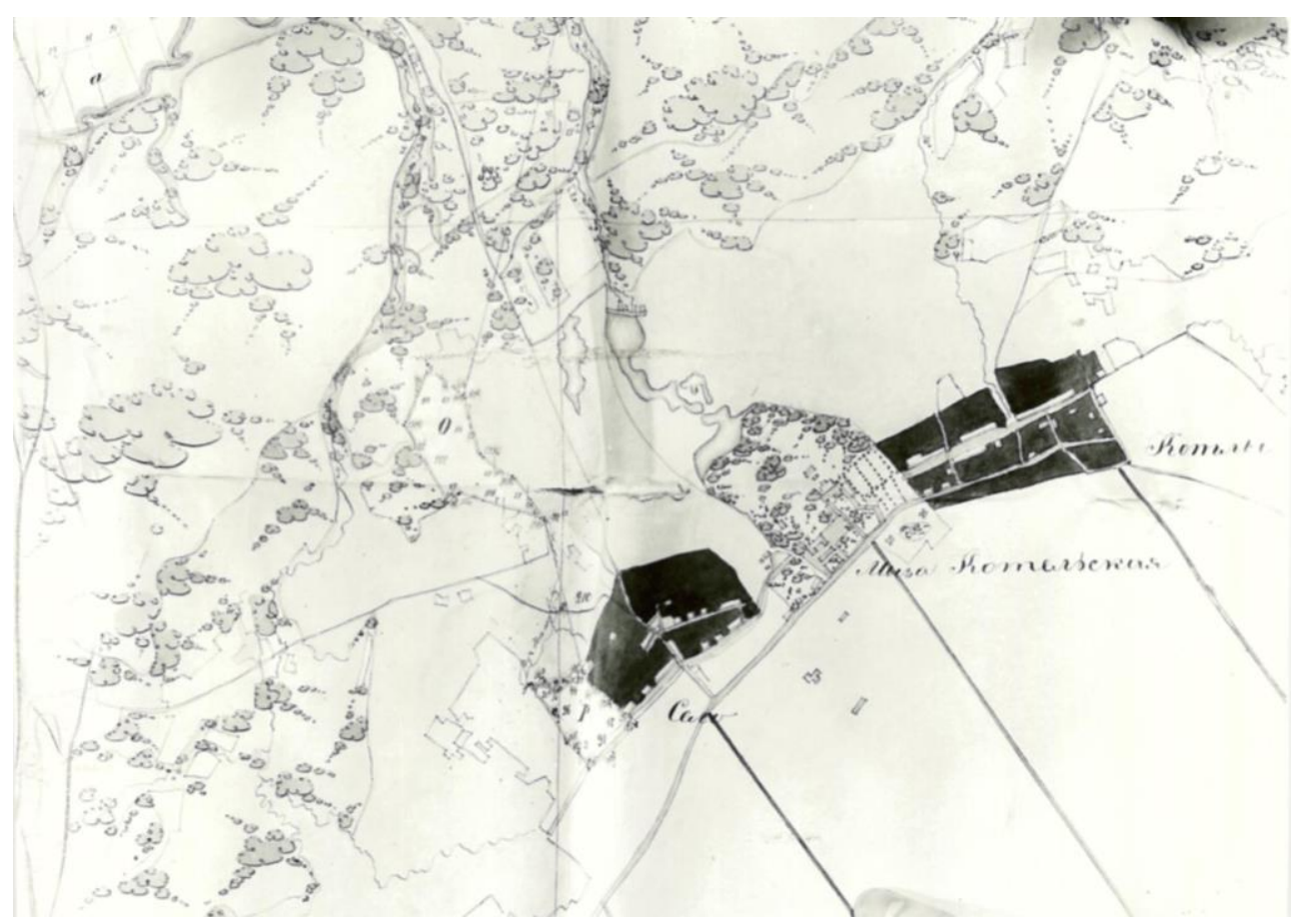

Fig. 2. Kotelskaya estate. CSHA SPb, F. 262, Op. 16, D. 69.

The average area of the nobles' estate in the Gdovskii uyezd is much smaller than ones in Luzhskii and Yamburgskii uyezds. Therefore, a typical estate with average indicators of the area and number of structures is taken as an example.

Gdovskii uyezd - Volyshovo estate.

The first information about the Volyshovo estate dates back to 1784. Its territory in the plan had a rectangular shape elongated perpendicular to the Vogosha river from east to west (Figure 5).

Stage 1 (end of the 18th century - 1800). The ownership of General-Lieutenant Tatyana Danilovna Ovtsina. The estate is indicated on the special geometrical plan of the Pskov province of Porhov district, according to which the complex, surrounded by a park, consists of a manor house, residential outbuildings, a church and a stable. 
Stage $2(1800$ - 1864). The ownership of Ekaterina Illarionovna Vasilchikova, since 1830 of her son Dmitry Vasilievich Vasilchikov. During this period, the estate included a wooden manor house, a brick stable, a stone outbuilding and a house church built in 1848 . In the 1840s, two buildings were erected in the central part of the estate for household purposes, which were a kitchen and a stud farm management, a stone arbor with a dovecote was built in 1852. In the second half of the 19th century, the construction on the estate area was led by architects Makarov and Popov.

Stage 3 (1864 - 1880). Ownership of Tatyana Dmitrievna Stroganova. The manor house was rebuilt in the mid-1860s, new cattle yards and a house for hunters were erected, stable and kennel were built in the 1880s.

Stage 4 (1880 - 1917). Ownership of Captain II rank Sergey Alexandrovich Stroganov. By the end of the XIX century, a complex of farm and residential buildings for a stud farm was built one verst from the estate. At the turn of the century, large-scale construction work is underway under the leadership of the manager, a new stone manor house, outbuildings and utility buildings were built.

After 1917, the state pedigree stud farm was founded on the basis of the existing factory, and in 1919 an agricultural institute was opened, which was later reorganized into a technical school and then to a school.

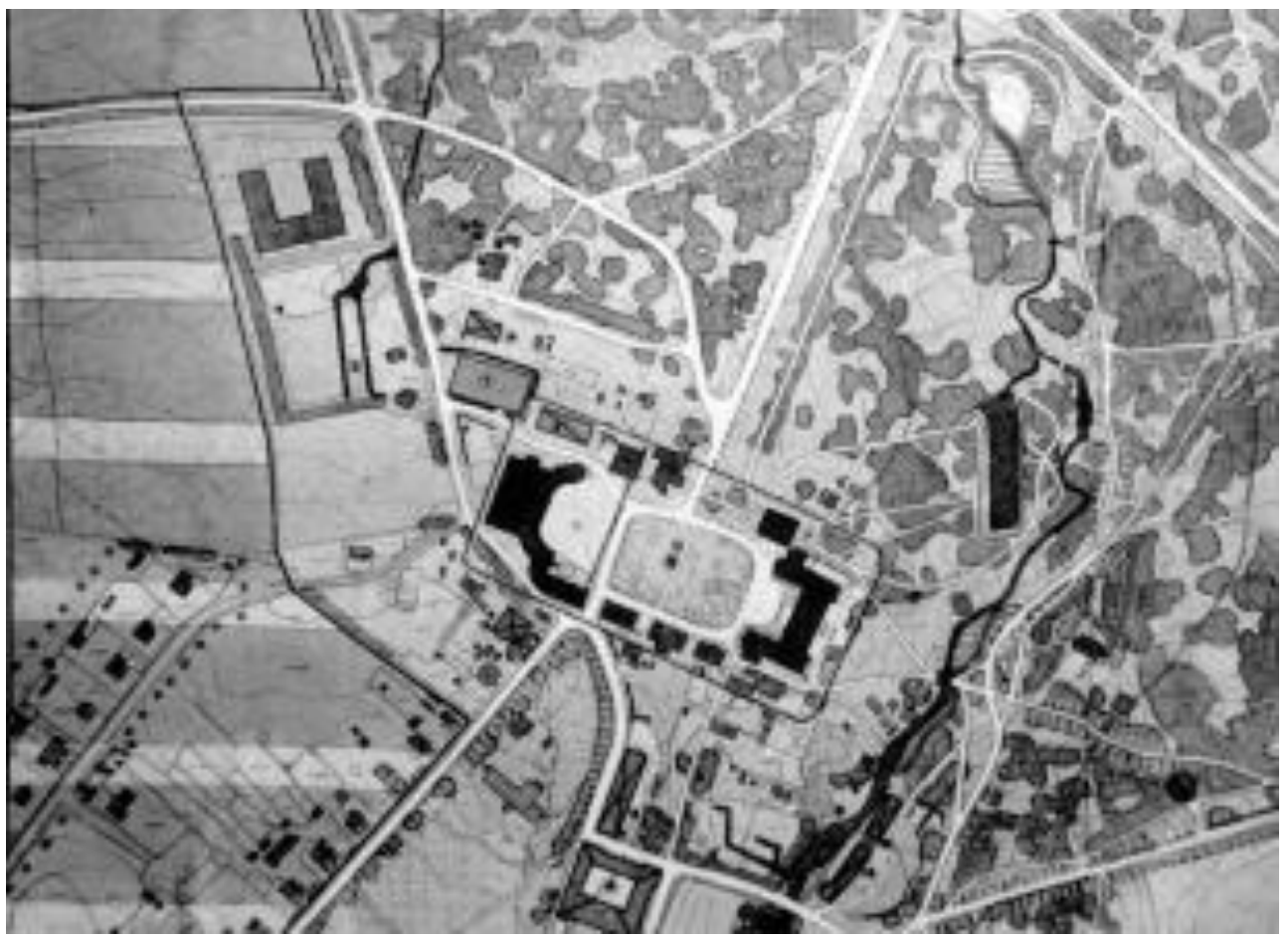

Fig. 3. Volyshovo estate. 18th -19 th centuries.

The fewest estates of the highest nobility among distant uyezds are located in Novoladozhskii uyezd. The estates located here, as a rule, do not exceed $10-15$ ha. As an example, a small, according to the standards of the far zone, estate with a small number of buildings was selected.

Novoladozhskii uyezd - Pokrovskoe estate.

The estate with an area of 15 ha is located near the right bank of the Volkhov River (Figure 6). 
Stage 1 (1779 - early 19th century). The ownership of an actual privy councilor Vasily Evdokimovich Adadurov. Since the 16th century, there was a church of the Intercession of the Holy Virgin in the Pokrovskoe village, in 1737 the building was replaced by a stone one. The manor buildings and peasant households were located to the east of the church along the stream banks. A regular park adjoined the manor courtyard located at the edge of the floodplain terrace.

Stage 2 (early 19th century - 1845). Ownership of Elizabeth Dmitrievna Adadurova and her son, Major General Vasily Vasilievich Adadurov. In the 1830 s - 1840s a stone clergy house with a library was built.

Stage 3 (1845 - 1890). The ownership of rear admiral Pyotr Alekseevich Karaulov, since 1856 - Victoria Mikhailovna Karaulova, since 1859 - the actual state counsillor Vasily Petrovich Karaulov.

In 1861, after the liberation of the peasants in the Pokrovskoe village was only the manor. The new manor house was built of wood, and the courtyard moved east. During this period, the park was renovated with the the historical regular layout preserved.

Subsequent owners (A.P. Karaulova since 1890, P.V. Karaulov since 1900, O.N. Karaulova since 1915) did not make significant changes to the existing estate, except reducing the area due to the gradual sale of its individual sections at the beginning of the 20th century.

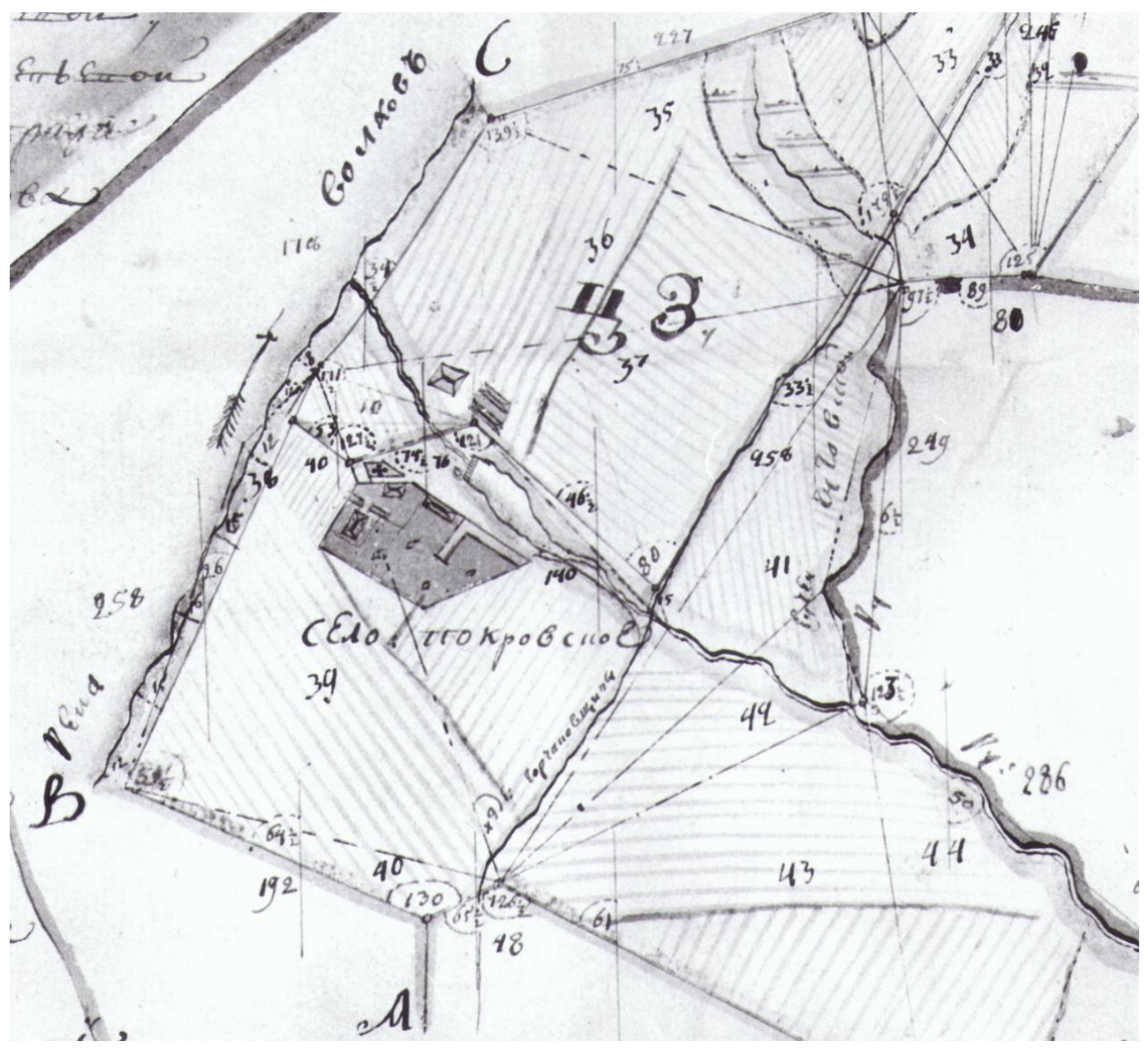

Fig. 4. Plan of the Pokrovskoe village. 1778, RSAAC, F. 1354, Op. 357/1, D. P-1cr. 


\section{Conclusions}

Despite the unity of signs associated with belonging to the highest nobility, estates located in the near and far districts have significant differences that determine their unique specificity.

Medium and small estates were located in large groups in the territories of border uyezds, also known as "bushes" or "nests" along the main land and water arterials, concentrating around the main representative estates, while having a significantly smaller area compared to the neighboring estates. The number of structures was also lower, their functional use was mainly of an economic nature, which was necessary for seasonal or year-round living.

Revealing the trends for developing and characteristic peculiarities of presentable estates of distant uyezds is not only necessary for determining their effect on the development of historical agglomeration, but also for additional studies on the issues of their preservation and modern use.

The author thanks N. M. Murashova, I. V. Barsova, S. E. Gusev, and N. G. Rozov.

\section{Referencies}

1. E.A. Kozyreva, Vestnik of TSUAB, 21 (3), 67 - 76 (2019) DOI: 10.31675/1607-18592019-21-3-67-76

2. S. Sementsov, N. Akulova, Advances in Social Science, Education and Humanities Research, 324, 425 - 433 (2019)

3. P. Roosevelt, Life on the Russian Country Estate: a Social and Cultural History (Yale University Press, London, 1995)

4. V. Jenkins, Land use Policy, 73, 73 - 83 (2018)

5. T. Matthews, D. Grant-Smith, Cities, 62, 152 - 158 (2017)

6. L. Lavrov, F. Perov, Proceedings of the institution of civil engineers: urban design and planning, 168 (5), 259 - 266 (2015) 